\title{
Prevalence and Clinical Manifestations of Ketosis in Cows in and Around Bikaner
}

\author{
Mohammed Nazeer, Sandeep Kumar, Manu Jaiswal*, Alok Mishra, \\ Grijesh Upmanyu, Pratyush Kumar and Sirigiri Ashok Kumar
}

Faculty of Veterinary and Animal Science, Institute of Agricultural Sciences, Rajiv Gandhi South Campus, Banaras Hindu University, Barkachha, Mirzapur, (U.P.), India

*Corresponding author

\begin{tabular}{|c|c|}
\hline & A B S T RA C T \\
\hline Keywords & \multirow{4}{*}{$\begin{array}{l}\text { The present study was conducted to determine prevalence of ketosis in cows in and around } \\
\text { Bikaner and clinical manifestations in ketotic cows. Based upon test results } 40 \text { cows were } \\
\text { diagnosed as ketotic. The overall prevalence of ketosis amongst post-parturient cows was } \\
\text { found to be } 11.42 \text { per cent, age-wise prevalence of ketosis was highest in } 8-9 \text { years of age } \\
\text { ( } 35 \text { per cent) and lowest in }>9 \text { ( } 5 \text { per cent) years of age, parity-wise prevalence of ketosis } \\
\text { was highest in } 3^{\text {rd }} \text { and } 4^{\text {th }} \text { parity ( } 25 \text { per cent) and lowest in } 1^{\text {st }} \text { and } 6^{\text {th }}(5 \text { per cent), stage of } \\
\text { lactation-wise prevalence of ketosis was highest in } 1-2 \text { i.e. } 45 \% \text { and lowest in } 4-5 \text { month } \\
\text { i.e } 2.5 \% \text { after parturition and month-wise prevalence of ketosis was highest in January ( } 25 \\
\text { per cent) and lowest in April ( } 13 \text { percent). The clinical examination of these animals } \\
\text { revealed non significant elevation in temperature and pulse rate but mild decrease in } \\
\text { respiration rate, but there was highly significant increase ( } P<0.01) \text { in ruminal movement } \\
\text { (per two min.) and milk yield (lt. Per day) in treated cows in all groups }(\mathrm{A}, \mathrm{B} \text { and } \mathrm{C}) \text {. }\end{array}$} \\
\hline $\begin{array}{l}\text { Ketosis, Prevalence, } \\
\text { Ketone bodies, } \\
\text { Post-parturient, } \\
\text { Ruminal Movement }\end{array}$ & \\
\hline Article Info & \\
\hline $\begin{array}{l}\text { Accepted: } \\
\text { 12 February } 2019 \\
\text { Available Online: } \\
10 \text { March } 2019\end{array}$ & \\
\hline
\end{tabular}

\section{Introduction}

According to livestock census (2007) Rajasthan has 1.24 crore cattle and 1.15 crore buffaloes. In that population Bikaner has 7.28 lacs cattle and 1.42 lacs buffaloes. The state produces approximately $8713 \mathrm{MT}$ of milk per year, which is approximately 11 per cent of total milk production in the country. At the onset of lactation, the dairy cow must accommodate a tremendous increase in energy demand by the mammary gland for milk production. This is realized partly by increasing feed intake and partly by fat mobilization from adipose tissue. However, excessive fat mobilization can induce an imbalance in hepatic carbohydrate and fat metabolism, characterized by elevated concentrations of ketone bodies called hyperketonemia Haelst et al., (2008). Ketosis is a production disease with high intensity of prolonged morbidity causing substantial loss in dairy industry (Holmes, 1950; Radostits et al., (2010). Ketosis has become a very common metabolic disorder in modern dairy production by causing decrease in milk production and increase in prevalence and duration of fresh cow diseases, enhancing 
time to conception, and augmenting risk of culling. The prevalence of ketosis in most of the common management systems after calving has not been explored entailing high production loss to the dairy farmers McKay (2012). Ketosis can be diagnosed by measuring ketone bodies present in urine, milk, and blood. Because of the economic consequences, it is imperative to diagnose ketosis in dairy cows, particularly during early lactation for treatment in advance and prevention of further losses. Bovine ketosis is of substantial economic significance and has been found to be responsible for decline in milk production even two weeks before its clinical appearance. Major economic losses have been attributed to the loss of milk yield and failure of the animals to return to the peak production potential even after recovery in clear cut cases of ketosis (Teli and Ali, 2007). In this study, prevalence of ketosis in cows in and around Bikaner was determined in respect of different months of year, different stages of lactation, different age group and different parities during 2017-2018.

\section{Materials and Methods}

Under the present study, a total of a total of 350 post parturient cows having a history of anorexia, drop in milk yield, history of parturition, feeding, stage of lactation and milk-yield was taken from owners. Observation was made regarding general symptoms and clinical observations including rectal temperature, pulse, respiration rate, ruminal movement and milk yield. Urine samples of 350 post-parturient cows belonging to the college dairy farm, outdoor patients brought for treatment at medicine clinic of College of Veterinary and Animal Science, Bikaner and individual animals shown by owners at their holdings in and around Bikaner were examined for prevalence of ketosis during 2017-2018.

\section{Treatment trials}

The ketotic animals under treatment were divided into three groups:

Group A $(n=15)$ received Isoflud (Zydus AHL) containing Isoflupredone Acetate (2 $\mathrm{mg} / \mathrm{ml}$ ) @ dose rate of $20 \mathrm{mg}$ per animal.

Group B $(n=15)$ received Decadurabolin (Cadilla Health Care Ltd.) containing Nandrolone Decanoate 100 mg per animal.

Group C $(n=10)$ showing glycosuria were given Human Actrapid (Insulin) containing 40 IU per $\mathrm{ml}$.

\section{Results and Discussion}

In the present investigation total of 350 post parturient cows having a history of anorexia and drop in milk yield were included. These cows were screened for ketosis using modified Rothera's test. Based upon test results 40 cows were diagnosed as ketotic. Prevalence of clinical ketosis in 40 cows with respect to age, parity, stage of lactation and month of year was studied.

\section{Overall prevalence}

The overall prevalence of ketosis amongst post-parturient cows was found to be 11.42 per cent. The disease emerged after parturition and the prevalence was higher mainly in (a) Colder month, (b) During first and second month after parturition, (c) Second to fifth parity, and (d) cows aged up to 9 years.

The present study is in agreement with previous findings of (Bihani, 2001; Sharma, 2006; Sahoo et al., 2009; Thirunavukkarasu et $a l ., 2010)$ who reported an overall prevalence of 12.50, 9.90, 10.20, 16.80 and 9.38 per cent, respectively. However, Yameogo et al., 
(2008) recorded low incidence rate of 4.40 and 6.43 per cent, and (Duffield, 2000; Pourjafar and Heidari, 2003) recorded higher incidence $30.33,34$ and 38 per cent, respectively in ketotic cows. The incidence can vary depending upon the breed, management practices and feeding regimens opted.

\section{Age-wise prevalence}

Analysis of age-wise prevalence of ketosis (Table 1) showed that it was highest in cows of in 8-9 years of age (35 per cent) followed by 7-8 (22.50 per cent), < 6 ( 20 per cent), 6-7 ( 17.50 per cent) and $>9$ ( 5 per cent) years of age. Similar findings were previously reported by (Mir and Malik, 2002; Bihani et al., 2001 and Sharma, 2006), who reported the highest prevalence of cows in the age group of 8-9 years.

\section{Parity-wise prevalence}

Parity-wise prevalence of ketosis (Table 2) was highest in $3^{\text {rd }}$ and $4^{\text {th }}$ parity ( 25 per cent), followed by $2^{\text {nd }}$ and $5^{\text {th }}$ (20 per cent) and $1^{\text {st }}$ and $6^{\text {th }}$ (5 per cent). The present investigation is in agreement with (Bihani, 2001; Sharma, 2006), who reported highest prevalence in $3^{\text {rd }}$ and $4^{\text {th }}$ parity.

\section{Lactation-wise prevalence}

Stage of lactation-wise prevalence of ketosis (Table 3) between 0-1, 1-2, 2-3, 3-4 and 4-5 month after parturition was $37.50,45,10,5$ and 2.50 per cent respectively. Similar findings were given by (Chakrabarti, 2006; Sharma, 2006; Teli and Ali, 2007; Radostitis et al., 2007; Nazifi et al., 2008), who have reported maximum cases within one month after parturition. These figures suggested that prevalence of clinical ketosis among lactating cows were maximum in first two months of lactation, when the animals are in peak phase of production. One of the reason is that at this stage there is maximum physiological stress due to post-parturient depletion of body reserves and lactational stress due to high milk production.

\section{Month-wise prevalence}

Month-wise prevalence of ketosis (Table 4) was highest in January (25 per cent), followed by February (20 percent), March (15 per cent), May and June (13.50 per cent) and April (13 percent). The present study is in agreement with (Bihani, 2001; Sharma, 2006; Radostitis et al., 2007). Who have reported highest prevalence in winter months because the animal have to divert a part of its energy to combat the stress of low temperature to maintain body temperature. Bhuin and Chakrabarti (1993) observed the highest incidence of ketosis from September to December month of the year.

\section{Rectal temperature, pulse rate, respiration rate, ruminal movement and milk yield}

The Mean \pm SE value of temperature, pulse rate, respiration rate, ruminal movements and milk yield in ketotic cows are presented in Table 5, 6 and 7 for group A, B and C respectively.

The Mean \pm SE value of temperature, pulse rate, respiration rate, ruminal movements and milk yield in ketotic cows in group A, B and $\mathrm{C}$ were $(101.48 \pm 0.15,101.44 \pm 0.20$ and $\left.101.48 \pm 20{ }^{\circ} \mathrm{F}\right),(56.27 \pm 1.02,55.80 \pm 0.73$ and $56.30 \pm 1.11$ per $\min .), \quad(19.27 \pm 0.63$, $19.33 \pm 0.57$ and $19.30 \pm 0.84$ per min.), $(1.60 \pm 0.19,1.60 \pm 0.13$ and $1.50 \pm 0.22$ per two min.) and $(5.58 \pm 0.15, \quad 5.33 \pm 0.22$ and $5.37 \pm 0.28$ lt. per day) respectively. The Mean $\pm \mathrm{SE}$ value of temperature, pulse rate, respiration rate, ruminal movements and milk yield in healthy cows were $101.26 \pm 0.23{ }^{\circ} \mathrm{F}$, $55.60 \pm 1.76$ per min., $19.90 \pm 0.90$ per min., 
$2.90 \pm 0.18$ per two min. and $15.50 \pm 1.04$ lt. per day, respectively.

Comparison of the results showed non significant elevation in temperature and pulse rate but mild decrease in respiration rate in all groups (A, B and C). Ruminal movement and milk yield were highly significant decreased $(\mathrm{P}<0.01)$ in all three groups $(\mathrm{A}, \mathrm{B}$ and $\mathrm{C})$ as compared to healthy values. The present study is in agreement with Sharma (2006). Similar findings were reported by Mir and Malik (2003). Panda (2003) reported 40.28 per cent reduction in milk yield in ketotic cows. Panda (2003) and Singh (2001) reported temperature, pulse rate and respiration rate were in normal physiological ranges. Ruminal movements and milk yield were reduced significantly $(\mathrm{p}<0.01)$.

Table.1 Age-wise prevalence

\begin{tabular}{|r|c|c|c|}
\hline S.No. & Occurrence of ketosis & No. of ketotic cows & Per cent prevalence \\
\hline $\mathbf{1 .}$ & Age of cows in year & & \\
\hline $\mathbf{2}$. & $<6$ & 8 & 20.0 \\
\hline $\mathbf{3 .}$ & $6-7$ & 7 & 17.50 \\
\hline $\mathbf{4}$. & $7-8$ & 9 & 22.50 \\
\hline $\mathbf{5 .}$ & $8-9$ & 14 & 35.0 \\
\hline
\end{tabular}

Table.2 Parity-wise prevalence

\begin{tabular}{|c|c|c|c|}
\hline S.No. & Occurrence of ketosis & No. of ketotic cows & Per cent prevalence \\
\hline & Parity of cows (Number) & & \\
\hline & First & 2 & 5.0 \\
\hline Second & 8 & 20.0 \\
\hline Third & 10 & 25.0 \\
\hline & Fourth & 10 & 25.0 \\
\hline & Fifth & 8 & 20.0 \\
\hline & Sixth & 2 & 5.0 \\
\hline
\end{tabular}

Table.3 Lactation-wise prevalence

\begin{tabular}{|r|c|c|c|}
\hline S.No. & $\begin{array}{c}\text { Occurrence of ketosis } \\
\text { Stage of lactation in month }\end{array}$ & No. of ketotic cows & Per cent prevalence \\
\hline $\mathbf{1 .}$ & First (0-1) & 15 & \\
\hline $\mathbf{2 .}$ & Second (1-2) & 18 & 37.50 \\
\hline $\mathbf{3 .}$ & Third (2-3) & 4 & 45.0 \\
\hline $\mathbf{4 .}$ & Fourth (3-4) & 2 & 10.0 \\
\hline $\mathbf{5 .}$ & Fifth (4-5) & 1 & 5.0 \\
\hline
\end{tabular}


Table.4 Month-wise prevalence (\%)

\begin{tabular}{|r|c|c|c|}
\hline S.No. & Occurrence of ketosis & No. of ketotic cows & Per cent prevalence \\
\hline & Month of the year & & \\
\hline $\mathbf{1 .}$ & January & 6 & 25.0 \\
\hline $\mathbf{2 .}$ & February & 5 & 20.0 \\
\hline $\mathbf{3 .}$ & March & 10 & 15.0 \\
\hline $\mathbf{4 .}$ & April & 6 & 13.0 \\
\hline $\mathbf{5 .}$ & May & 8 & 13.50 \\
\hline 6. & June & 5 & $13.50 \mathrm{~s}$ \\
\hline
\end{tabular}

Table.5 Mean \pm SE value of clinical parameters in apparently healthy and ketotic cows (before and after treatment with Isofluid) (Group: A)

\begin{tabular}{|c|c|c|c|c|}
\hline S.No. & Parameters & $\begin{array}{c}\text { Healthy Cows } \\
(\mathbf{n = 1 0})\end{array}$ & $\begin{array}{c}\text { Before treatment } \\
(n=15)\end{array}$ & $\begin{array}{l}\text { After treatment } \\
\qquad(N=15)\end{array}$ \\
\hline 1 & $\begin{array}{c}\text { Body Temperature } \\
\left({ }^{\circ} \mathrm{F}\right)\end{array}$ & $101.26 \pm 0.23^{\mathrm{a}}$ & $101.48 \pm 0.15^{\mathrm{a}}$ & $101.51 \pm 0.11^{\mathrm{a}}$ \\
\hline 2 & Pulse Rate/Min & $55.60 \pm 1.76^{\mathrm{a}}$ & $56.27 \pm 1.02^{\mathrm{a}}$ & $56.47 \pm 0.77^{\mathrm{a}}$ \\
\hline 3 & Respiration Rate/Min & $19.90 \pm 0.90^{\mathrm{a}}$ & $19.27 \pm 0.63^{\mathrm{a}}$ & $19.87 \pm 0.53^{\mathrm{a}}$ \\
\hline 4 & $\begin{array}{l}\text { Ruminal Movement/2 } \\
\text { Min }(* *)\end{array}$ & $2.90 \pm 0.18^{\mathrm{c}}$ & $1.60 \pm 0.19^{a}$ & $2.13 \pm 0.09^{b}$ \\
\hline 5 & $\begin{array}{l}\text { Milk Yield (in lit.) per } \\
\text { day }(* *)\end{array}$ & $15.50 \pm 1.04^{\mathrm{c}}$ & $5.58 \pm 0.15^{\mathrm{a}}$ & $8.77 \pm 0.32^{b}$ \\
\hline
\end{tabular}

$*(\mathrm{p}<0.05) * *(\mathrm{p}<0.01)$

Means with different superscripted letters in the same row differ significantly

Table.6 Mean \pm SE value of clinical parameters in apparently healthy and ketotic cows (before and after treatment with Decadurabolin) (Group: B)

\begin{tabular}{|c|c|c|c|c|}
\hline S.No & Parameters & $\begin{array}{c}\text { Healthy Cows } \\
(\mathbf{n = 1 0})\end{array}$ & $\begin{array}{c}\text { Before treatment } \\
(\mathbf{n = 1 5})\end{array}$ & $\begin{array}{c}\text { After treatment } \\
(\mathbf{N}=\mathbf{1 5})\end{array}$ \\
\hline $\mathbf{1}$ & Body Temperature & $101.26 \pm 0.23^{\mathrm{a}}$ & $101.44 \pm 0.20^{\mathrm{a}}$ & $101.53 \pm 0.15^{\mathrm{a}}$ \\
\hline $\mathbf{2}$ & $\begin{array}{c}\left.{ }^{\circ} \mathrm{F}\right) \\
\text { Pulse Rate/Min }\end{array}$ & $55.60 \pm 1.76^{\mathrm{a}}$ & $55.80 \pm 0.73^{\mathrm{a}}$ & $56.13 \pm 0.81^{\mathrm{a}}$ \\
\hline $\mathbf{3}$ & Respiration Rate/Min & $19.90 \pm 0.90^{\mathrm{a}}$ & $19.33 \pm 0.57^{\mathrm{a}}$ & $19.33 \pm 0.63^{\mathrm{a}}$ \\
\hline $\mathbf{4}$ & Ruminal Movement/2 Min $(* *)$ & $2.90 \pm 0.18^{\mathrm{b}}$ & $1.60 \pm 0.13^{\mathrm{a}}$ & $2.73 \pm 0.12^{\mathrm{b}}$ \\
\hline $\mathbf{5}$ & Milk Yield (in lit.) per day $(* *)$ & $15.50 \pm 1.04^{\mathrm{c}}$ & $5.33 \pm 0.22^{\mathrm{a}}$ & $9.35 \pm 0.32^{\mathrm{b}}$ \\
\hline
\end{tabular}

$*(\mathrm{p}<0.05) * *(\mathrm{p}<0.01)$

Means with different superscripted letters in the same row differ significantly 
Table.7 Mean \pm SE value of clinical parameters in apparently healthy and ketotic cows (before and after treatment with Insulin) (Group: C)

\begin{tabular}{|c|c|c|c|c|}
\hline S.No. & Parameters & $\begin{array}{c}\text { Healthy Cows } \\
(\mathbf{n = 1 0})\end{array}$ & $\begin{array}{c}\text { Before treatment } \\
(\mathbf{n = 1 5})\end{array}$ & $\begin{array}{c}\text { After treatment } \\
(\mathbf{N = 1 5})\end{array}$ \\
\hline $\mathbf{1}$ & $\begin{array}{c}101.26 \pm 0.23^{\mathrm{a}} \\
\text { Body Temperature } \\
\left({ }^{\circ} \mathrm{F}\right)\end{array}$ & $101.48 \pm 0.20^{\mathrm{a}}$ & $101.64 \pm 0.18^{\mathrm{a}}$ \\
\hline $\mathbf{2}$ & Pulse Rate/Min & $55.60 \pm 1.76^{\mathrm{a}}$ & $56.30 \pm 1.11^{\mathrm{a}}$ & $56.60 \pm 0.98^{\mathrm{a}}$ \\
\hline $\mathbf{3}$ & Respiration Rate/Min & $19.90 \pm 0.90^{\mathrm{a}}$ & $19.30 \pm 0.84^{\mathrm{a}}$ & $19.70 \pm 0.87^{\mathrm{a}}$ \\
\hline $\mathbf{4}$ & Ruminal Movement/2 Min (**) & $2.90 \pm 0.18^{\mathrm{b}}$ & $1.50 \pm 0.22^{\mathrm{a}}$ & $2.50 \pm 0.17^{\mathrm{b}}$ \\
\hline $\mathbf{5}$ & Milk Yield (in lit.) per day (**) & $15.50 \pm 1.04^{\mathrm{c}}$ & $5.37 \pm 0.28^{\mathrm{a}}$ & $8.87 \pm 0.41^{\mathrm{b}}$ \\
\hline
\end{tabular}

$*(\mathrm{p}<0.05) * *(\mathrm{p}<0.01)$

Means with different superscripted letters in the same row differ significantly

In conclusion, the overall prevalence of ketosis amongst post-parturient cows was found to be 11.42 per cent, age-wise prevalence of ketosis was highest in 8-9 years of age (35 per cent) and lowest in $>9$ ( 5 per cent) years of age, parity-wise prevalence of ketosis was highest in $3^{\text {rd }}$ and $4^{\text {th }}$ parity $(25$ per cent) and lowest in $1^{\text {st }}$ and $6^{\text {th }}$ (5 per cent), stage of lactation-wise prevalence of ketosis was highest in 1-2 i.e 45\% and lowest in 4-5 month i.e $2.5 \%$ after parturition and monthwise prevalence of ketosis was highest in January (25 per cent) and lowest in April (13 percent). Non significant elevation in temperature and pulse rate but mild decrease in respiration rate but ruminal movement and milk yield were highly significant decreased $(\mathrm{P}<0.01)$ in all three groups $(\mathrm{A}, \mathrm{B}$ and $\mathrm{C})$.

\section{References}

Bhuin, S. and Chakrabarti, A. (1993). A note on the prevalence of ketosis in cows in West Bengal. Indian Veterinary Journal, 70(6): pp 582 - 583.

Bihani, D.K. (2001). Clinico-biochemical studies on ketosis in cattle, Ph.D. thesis submitted to Rajasthan Agricultural University, Bikaner.

Chakrabarti, A. (2006). Text book of clinical veterinary medicine $2^{\text {nd }}$ edn, Kalyani publishers, Ludhiana. pp 621 - 631, $564-577$.

Duffield, T.F. (2000). Subclinical ketosis in lactating dairy cattle. In metabolic disorder in ruminants. Veterinary Clinics of North America: Food Animal Practice, 16: 231.

Haelst Van, Y.N.T., Beeckman, A., Knegsel Van, A.T.M. and Fievez, V. (2008). Elevated concentration of Oleic Acid and long-chain fatty acids in milk fat of Multiparous Subclinical Ketotic Cows. Journal of Dairy Science, 91: 4683 - 4686.

Holmes, J.R. (1950). Observations on the incidence of subclinical ketosis in a dairy herd. British Veterinary Journal, 106: 365-377.

McKay, S. (2012). Subclinical ketosis: Frequent and an expensive problem. Tijdschr Diergeneeskd, 137: 686-687.

Mir, A.Q. and Malik, H.U. (2002). Prevalence and clinic-pathological studies in 
bovine ketosis. National symposium and XX ISVM convention, Bikaner: pp 125.

Mir, A.Q. and Malik, H.U. (2003). Utility of clinical symptomatology in diagnosis of bovine ketosis under field condition. Indian Journal of Veterinary Medicine, 23(2): pp 104 105.

Nazifi, S., Fani, M., Rowghani, E. and Behbood, M.R. (2008). Studies on the relationship between sub-clinical ketosis and liver injuries within the first two month of lactation in high producing. International Journal of Dairy Science, 3: 29 - 35.

Panda, A. (2003). Studies on some aspects of Clinico-biochemical changes of bovine ketosis and its therapy. M.V.Sc. Thesis submitted to Orissa University of Ag. and Technology, Bhubaneswar (Orissa).

Pourjafar, M. and Heidari, M. (2003). A study on sub-clinical ketosis in holstein cattle of Torbat-Heydaries. Acta Veterinaria Scandinavica, 98: 315.

Radostits O M, Gay C C, Hinchcliff K W, Constable $\mathrm{P}$ D. In Veterinary Medicine: A Text Book of the Diseases of Cattle, Horses, Sheep, Pigs and Goats. $10^{\text {th }}$ Ed, Saunders Elsevier, London, 2007, pp 14521462.

Radostits, O.M., Gay, C.C., Hinchcliff, K. and Constable, P.D. (2010) Veterinary Medicine: A Textbook of the Diseases of Cattle, Horses, Sheep, Pigs and
Goats. 10th ed. Saunders Elsevier, Philadelphia, PA.

Sahoo, S.S.; Patra, R.C,; Behara, P.C. and Swarup, D. (2009). Oxidative stress indices in the erythrocytes from tha lactating cows after treatment for subclinical ketosis with antioxidant incorporated in the therapeutic regime. Veterinary Research Communications. 33(3): 281 - 90.

Sharma, B.L. (2006). Studies on some biochemical and hormonal changes in ketotic cows in Bikaner region. M.V.Sc. thesis, Rajasthan Agricultural University, Bikaner.

Singh, G. (2001). Studies on Haematobiochemical aspects of ketosis in buffaloes in Bikaner. M.V.Sc. Thesis, Rajasthan Agricultural University, Bikaner.

Teli, S.A. and Ali, S.L. (2007). Economic Implications of Bubaline ketosis. Vetscan vol 2 (1), Article-14.

Thirunavukkarasu, M., Kathiravan, G., Kalaikannan, A. and Jebarani, W. (2010). Prevalance of ketosis in dairy farm. Tamil Nadu Journal of Veterinary Science and Animal, 6(4): 193 - 195.

Yameogo, N., Ouedraogo, G.A., Kanyandekwe, C. and Sawadogo, G.J. (2008). Relationship between ketosis and dairy cows blood metabolite in intensive production farms of the periurban area of Dakar. Tropical Animal Health and Production, 40: 483-490.

\section{How to cite this article:}

Mohammed Nazeer, Sandeep Kumar, Manu Jaiswal, Alok Mishra, grijesh Upmanyu, Pratyush Kumar and Sirigiri Ashok Kumar. 2019. Prevalence and Clinical Manifestations of Ketosis in Cows in and Around Bikaner. Int.J.Curr.Microbiol.App.Sci. 8(03): 1554-1560. doi: https://doi.org/10.20546/ijcmas.2019.803.179 